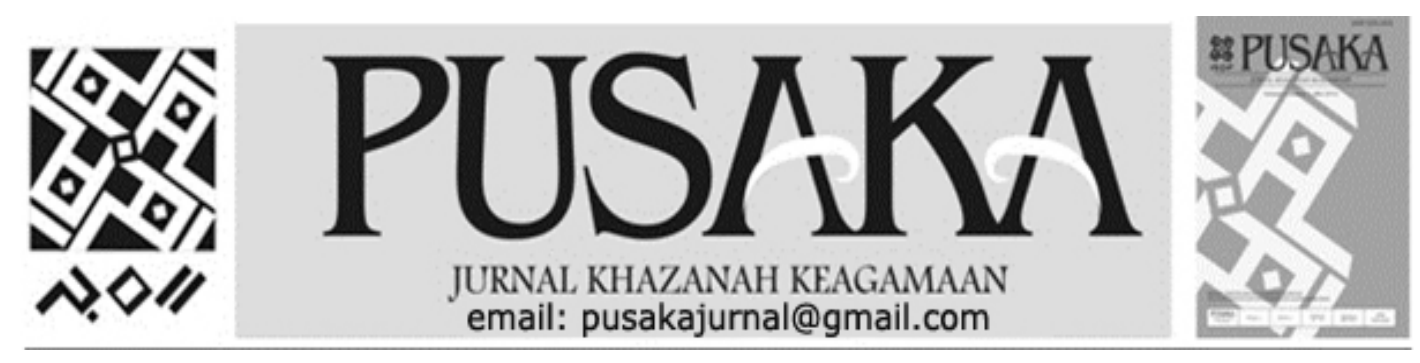

\title{
Perubahan Relasi Antarumat Beragama Di Manado \\ (Kasus Pendirian Rumah Ibadat Pasca PBM 2006)
}

\author{
Change Of Relations Between Religious In Manado \\ (Case Of Estbablishment Of Worship House Post PBM 2006)
}

\author{
Muhammad Irfan Syuhudi \\ Balai Penelitian dan Pengembangan Agama Makassar \\ Jl.A.P.Pettarani No.72 Makassar. Telp:0411-452952 \\ Email: irfansyuhudi@gmail.com
}

\begin{tabular}{|c|c|}
\hline $\begin{array}{c}\text { Info } \\
\text { Artikel }\end{array}$ & Abstract \\
\hline $\begin{array}{c}\text { Diterima } \\
19 \\
\text { Januari } \\
2017 \\
\text { Revisi I } \\
1 \\
\text { Maret } \\
2017\end{array}$ & $\begin{array}{l}\text { Relasi antarumat beragama di Kota Manado sejauh ini tergolong baik. Beberapa } \\
\text { hasil penelitian telah membuktikan hal tersebut. Namun, sejak terbit dan kemudian } \\
\text { pemerintah memberlakukan Peraturan Bersama Menteri (PBM) nomor } 9 \text { dan } 8 \\
\text { tahun } 2006 \text { terkait pendirian rumah ibadat, relasi sosial di antara masing-masing } \\
\text { pemeluk agama mulai terlihat kurang harmonis. Penelitian ini adalah penelitian } \\
\text { kualitatif dengan menyajikan data-data secara deskriptif. Pengumpulan data } \\
\text { melalui wawancara, observasi, dan penelusuran internet. Hasil penelitian } \\
\text { menunjukkan, kehadiran PBM nomor } 9 \text { dan } 8 \text { tahun } 2006 \text { secara tidak langsung } \\
\text { mengubah relasi sosial antarumat beragama di Manado. Sebelum regulasi tersebut } \\
\text { diberlakukan, penganut agama tidak kesulitan untuk membangun rumah ibadatnya } \\
\text { di lokasi manapun. Bahkan, antara pemeluk agama satu dengan yang lain terlihat } \\
\text { saling tolong menolong. Namun, sejak PBM nomor } 2006 \text { terbit, pemeluk agama } \\
\text { mulai merasakan kesulitan mendirikan rumah ibadat, terutama dari kelompok } \\
\text { agama minoritas. } \\
\text { Kata kunci: Relasi sosial, PBM 2006, rumah ibadat, Manado }\end{array}$ \\
\hline $\begin{array}{c}\text { Disetujui } \\
17 \\
\text { April } \\
2017\end{array}$ & $\begin{array}{l}\text { Relation between religious people in Manado City so far is quite good. Several } \\
\text { studies have proven this. However, since the publication and then the government } \\
\text { enacted the Joint Ministerial Regulation (PBM) number } 9 \text { and } 8 \text { of } 2006 \text { related to } \\
\text { the establishment of the synagogue, social relations among each of the followers of } \\
\text { religion began to look less harmonious. This research is a qualitative research by } \\
\text { presenting descriptive data. Data collection through interviews, observation, and } \\
\text { internet search. The results showed that the presence of PBM number } 9 \text { and } 8 \text { of } \\
2006 \text { indirectly changed the social relations between religious people in Manado. } \\
\text { Before the regulation was enacted, adherents of religion were not difficult to build } \\
\text { their House of worshipin any location. In fact, between followers of religion with } \\
\text { each other looks help each other. However, since the number of } 2006 \text { PBM } \\
\text { published, followers of religion began to feel the difficulty of building House of } \\
\text { worship, especially from minority religious groups. } \\
\text { Keywords: Social relation, PBM 2006, House of worship, Manado }\end{array}$ \\
\hline
\end{tabular}




\section{PENDAHULUAN}

Setiap pemeluk agama meyakini rumah ibadat adalah tempat yang sakral dan penuh nuansa spiritual. Sejatinya, keberadaan rumah ibadat bagi setiap pemeluk agamaadalah untuk mendekatkan diri dengan Tuhannya. Padahal, dalam hal ini, negara cukup jelas mengatur dan menjamin semua warganya untuk memilih agama dan menjalankan ritual keagamaannya masing-masing. Hal tersebut tertuang di dalam Undang-Undang Dasar 1945 , tepatnya pasal 29 ayat 1 dan 2 . Dalam Peraturan Menteri Agama RI tahun 2010 tentang Rencana Strategi Departemen Agama tahun 20102014, termaktub pula lima pokok yang menjadi tanggung jawab Departemen Agama dalam menyelenggarakan pembangunan bidang agama, yang dua di antaranya adalah fokus kepada kehidupan keagamaan, yaitu peningkatan kualitas kehidupan beragama dan peningkatan kerukunan umat beragama.

Sayang, keberadaan rumah ibadat, akhir-akhir ini, kerap kali dipersoalkan. Ia bahkan menjadi persoalan yang dianggap rawan untuk mengganggu kerukunan umat beragama di Indonesia. Permasalahannya pun variatif. Mulai penolakan pendirian rumah ibadat, penertiban rumah ibadat, hingga penutupan rumah ibadat. Hal ini ditegaskan pula oleh Kustini (2009:1), yang menyebutkan, pembangunan rumah ibadat merupakan salah satu masalah yang dapat mengganggu terwujudnya kerukunan umat beragama. Masalah tersebut muncul antara lain karena belum adanya kejelasan mengenai persyaratan dan tata-cara pendirian rumah ibadat, proses perizinan pendirian rumah ibadat sering berlarut-larut, penyalahgunaan rumah tinggal atau bangunan lain yang difungsikan sebagai rumah ibadat, pendirian atau keberadaan rumah ibadat yang tidak sesuai dengan prosedur yang berlaku dan tidak sesuai dengan aspirasi masyarakat setempat.

Belum

lama ini, Tribunnews.com, memberitakan dua aksi kekerasan yang dilakukan puluhan warga terhadap pemeluk Katolik dan Kristen di Kabupaten Sleman, Jawa Tengah, Mei dan Juni 2014. Pada peristiwa pertama terjadi 29 Mei 2014, rumah penganut Katolik, Julius Felicianus (54), di Dusun Tanjungsari, Desa Sukoharjo, Kecamatan Ngaglik, Sleman, diserang puluhan orang saat mereka berdoa Rosario bersama di rumah itu. Akibat penyerangan itu, lima orang terluka. Sedang peristiwa kedua (1 Juni 2014), adalah protes puluhan warga terhadap aktivitas peribadatan umat Kristen, disertai perusakan gedung bangunan milik pendeta NL yang digunakan sebagai tempat ibadat. Bangunan yang bersebelahan dengan rumah pendeta NL itu, terletak di Dusun Pangukan, Desa Tridadi, Sleman. Penyerangan bermula saat NL bersama sejumlah anggota jemaatnya menggelar kebaktian di bangunan sekitar pukul 08.30 WIB (Kapolri: Yang tak Boleh, Fungsi Rumah Jadi Mesjid dan Gereja, dalam http://www.tribunnews.com/nasional /2014/06/04/kapolri-yang-tak-bolehfungsi-rumah-jadi-mesjid-dan-gereja, diakses pada 3 Juni 2014). 
Beberapa lembaga pengkajian dalam laporan tahunnya mencatat adanya kecenderungan yang meningkat berkenaan pendirian rumah ibadat. The Wahid Institute mencatat, 62 kasus dengan rincian 28 kasus pelanggaran dan 34 kasus tindakan intoleransi tehadap rumah ibadat. Angka ini lebih besar dari jumlah angka kasus tahun 2009, meski ada perluasan wilayah laporan (The Wahid Institute, 2011: 17). Sementara, SETARA Institute pada 2010 menemukan 59 tempat ibadat yang mengalami gangguan dalam berbagai bentuk, baik penyerangan, penyegelan, penolakan, larangan aktivitas ibadah, dan lain-lain (SETARA Institute, 2011:9).

$$
\text { Pada 2011, Puslitbang }
$$

Kehidupan Keagamaan Badan

Litbang Diklat Kementerian Agama RI melakukan penelitian seputar Kasus-kasus Pendirian Rumah ibadat di Kawasan Timur Indonesia (Khusus Rumah Ibadat Umat Islam). Penelitian tersebut dilakukan di 5 provinsi, yaitu Sulut, Bali, NTT, Papua, dan Papua Barat. Penelitian tersebut menemukan 20 kasus penolakan pendirian rumah ibadat di 5 provinsi tersebut.

Di tempat lain, Kota Kendari, fenomena berkenaan pendirian rumah ibadat pasca PBM 2006, juga pernah terjadi. Hanya saja, atmosfirnya tidak terlalu tinggi. Yang sering menjadi persoalan adalah keberatan 60 warga yang bermukim di sekitar rumah ibadat dan 90 jamaah dari agama tertentu. Meski begitu, belum ada yang namanya penolakan dan aksi perusakan terkait berdirinya sebuah bangunan rumah ibadat. Kalau pun sempat muncul riak-riak di awal pendirian rumah ibadat, itu hanyalah sebatas protes warga (terutama orang Islam), yang ujung-ujungnya berakhir kepada penyelesaian secara musyawarah dan mempersilakan umat agama tertentu untuk membangun rumah ibadatnya (Syuhudi, 2014).

Beberapa kasus terkait pelarangan untuk mendirikan rumah ibadat, apalagi ada yang disertai tindak kekerasan, serta merta membuat penganut agama tertentu dilanda keresahan. Kehadiran Peraturan Bersama Menteri (PBM) Menteri Agama dan Menteri Dalam Negeri Nomor 9 dan Nomor 8 tahun 2006 tentang Pedoman Pelaksanaan Tugas Kepala Daerah/Wakil Kepala Daerah Dalam Pemeliharaan Kerukunan Umat Beragama, Pemberdayaan Forum Kerukunan Umat Beragama, dan Pendirian Rumah Ibadat, yang diharapkan mampu untuk menertibkan dan mendisiplinkan soal pendirian rumah ibadat, ternyata belum bisa dijadikan panduan. Bahkan, dalam beberapa kasus di Indonesia, termasuk di Kota Manado, yang menjadi fokus tulisan ini, PBM (khususnya pendirian rumah ibadat) justru malah mendatangkan pertikaian di antara umat beragama. Setidaknya, sejak PBM itu terbit, masih saja terjadi penolakan, penyerangan, larangan aktivitas ibadah di beberapa daerah di Indonesia.

Secara umum, tulisan ini hanya ingin menjawab pertanyaan mengenai relasi sosial antarumat beragama pra dan pasca berlakunya PBM tahun 2006, serta tanggapan masyarakat terhadap kehadiran PBM 2006 tersebut. 


\section{Kajian Teori}

\section{Relasi (Kelompok) Mayoritas- Minoritas}

Secara sederhana, istilah mayoritas dan mayoritas sebenarnya mengandung arti jumlah secara keseluruhan. Mayoritas diartikan berjumlah banyak, sedangkan minoritas berjumlah sedikit. Namun, lambat laun, istilah tersebut mengalami pergeseran makna, dan mengandung sebuah tekanan politis di dalamnya. Dalam Kamus Besar Bahasa Indonesia (KBBI), mayoritas diartikan jumlah orang terbanyak yang memperlihatkan ciri tertentu menurut suatu patokan dibandingkan dengan jumlah yang lain yang tidak memperlihatkan ciri itu. Sementara, minoritas adalah golongan sosial yang jumlah warganya jauh lebih kecil jika dibandingkan dengan golongan lain dalam suatu masyarakat dan karena itu didiskriminasikan oleh golongan lain.

Istilah mayoritas dan minoritas mengandung muatan politik. Ia awalnya hanya dikenal dalam konsep politik (terutama berkaitan pemilihan), dan dalam kondisi seperti ini, kelompok mayoritas selalu merasa diuntungkan. Meskipun begitu, ada juga kelompok minoritas yang memegang kendali atau berkuasa di tengah-tengah kelompok mayoritas. Misalkan, mayoritas penduduk di Afrika Selatan berkulit hitam, namun yang menjadi penguasa politik di sana adalah kulit putih (Liliweri, 2005:113).

Sebagian besar ahli berpendapat, relasi mayoritas dan minoritas mengandung penekanan yang kerap kali merugikan kelompok minoritas. Ruang gerak kelompok minoritas dibatasi, terkontrol, dan terkadang tidak bebas meluapkan ekspresi kelompoknya. Minoritas berada pada posisi "dianak-tirikan", terpinggirkan, dan disubordinatkan. Dalam hal demografi, misalnya, pengertian minoritas adalah mereka yang kehidupan sosialnya terbatas, bersifat lokal, dan tidak mempunyai kekuatan sosial untuk mempengaruhi kehidupan masyarakat luas setempat melalui arena-arena politik yang ada. Masyarakat luas diartikan sebagai golongan dominan. Melalui kekuatan sosial yang dimiliki, masyarakat luas dapat mendefinisikan pola-pola kehidupan secara umum maupun secara khusus mengenai apa yang sebaiknya atau seharusnya dijalani golongan minoritas (Suparlan, 1995:19-20).

Kelompok mayoritas dalam suatu masyarakat merupakan kelompok yang merasa memiliki kekuasaan untuk mengontrol dan mempengaruhi penyelenggaraan pemerintahan, agama, pendidikan, dan pekerjaan (ekonomi). Sebaliknya, kelompok minoritas kurang mempunyai akses terhadap sumber daya, privelese, dan tidak berpeluang mendapat kekuasaan seperti mayoritas, sehingga mendorong prasangka, bahwa kelompok minoritas lebih rendah kedudukannya daripada mayoritas (Liliweri, 2005:102).

Wagley dan Harris menyatakan dalam (Liliweri, 2005: 108), setiap kelompok minoritas atau kelompok subordinasi memiliki lima karakteristik, yaitu 1) selalu mengalami perlakuan tidak adil atau tidak seimbang; 2) dapat dibedakan berdasarkan ciri fisik atau 
kebudayaan; 3) keanggotaan meliputi orang dalam; 4) tidak bebas menikah; dan 5) sadar bahwa mereka tersuborinasi. Berdasarkan konsep mayoritas dan minoritas itu, kita dapat menetapkan karakteristik kelompok minoritas, yakni 1) relatif kurang berpengaruh/berkuasa; 2) menunjukkan diferensiasi yang berbeda dari mayoritas; 3) selalu distreotip dengan negatif, dan 4) diperlakukan secara tidak adil (Liliweri, 2005:106).

\section{Pembangunan Rumah Ibadat Berdasar PBM No. 9 dan 8/2006}

Persoalan rumah ibadat dalam PBM Nomor 9 dan 8 tahun 2006 dibahas dalam 3 Bab dan 10 pasal, yaitu Bab IV (Pendirian Rumah Ibadat) mulai dari pasal 13 hingga pasal 17, Bab V (Izin Sementara Pemanfaatan Bangunan Gedung) dari pasal 18 hingga pasal 20, dan Bab VI (Penyelesaian Perselisihan) pasal 21 dan 22.

Dalam pasal 13 disebutkan: (1) Pendirian rumah ibadat didasarkan pada keperluan nyata dan sungguhsungguh berdasarkan komposisi jumlah penduduk bagi pelayanan umat beragama yang bersangkutan di wilayah kelurahan/desa.

Pendirian rumah ibadat sebagaimana yang dimaksud pada ayat (1) dilakukan dengan tetap menjaga kerukunan umat beragama, tidak mengganggu ketentraman dan ketertiban umum, serta memenuhi aturan perundang-undangan. (3) Dalam hal keperluan nyata bagi pelayanan umat beragama sebagaimana dimaksud ayat (1) tidak terpenuhi, pertimbangan jumlah komposisi penduduk digunakan batas wilayah kecamatan atau kabupaten/kota atau provinsi.

Mengenai syarat pendirian rumah ibadat diatur dalam pasal 14 , yaitu; Pendirian rumah iabdat harus menenuhi persyaratan administratif dan persyaratan teknis bangunan gedung (ayat 1). Adapun syaratsayaratnya adalah memiliki pengguna yang ditandai dengan KTP pengguna yang disahkan oleh pejabat setempat, dukungan masyarakat setempat paling sedikit 60 orang yang disahkan oleh lurah/kepala desa, rekomendasi tertulis kepala departemen agama kabupaten/kota, dan rekomendasi tertulis FKUB kabupaten/kota. Jika syarat dukungan paling sedikit 60 orang warga setempat tidak terpenuhi, maka PBM mewajibkan kepada pemerintah setempat untuk memfasilitasi tersedianya lokasi pembangunan rumah ibadat (pasal 14 ayat 3 ).

Mengenai pemanfaatan sementara bangunan gedung sebagai rumah ibadat sementara diatur dalam pasal 18 ayat (3) dengan ketentuan syarat; izin tertulis dari pemilik bangunan, rekomendasi tertulis dari kepala desa/lurah, pelaporan tertulis kepada FKUB kabupaten/kota, dan pelaporan tertulis kepada kepala kantor kementerian agama kabupaten/kota. Surat keterangan pemberian izin sementara tersebut sebagaimana diatur dalam pasal 19 ayat (2) diberikan paling lama dua tahun.

\section{Metode Penelitian}

Pendekatan yang digunakan adalah kualitatif, yang menghasilkan data deskriptif berupa kata-kata tertulis atau lisan dari orang-orang dan perilaku yang dapat diamati 
(Endraswara,

2006:85-86).

Sebagaimana lazimnya penelitian kualitatif, peneliti dalam hal ini sekaligus merupakan instrumen penelitian. Pengumpulan data melalui wawancara dan observasi (Moleong, 2010: 174-202 dan Endraswara, 2006a: 213-214), dan wawancara dilakukan dengan pengurus rumah ibadat, tokoh agama, dan masyarakat setempat. Pengumpulan data juga melalui dokumentasi dan pencarian di internet terkait tema penelitian. Analisis data dilakukan dengan menelaah seluruh data yang tersedia dari berbagai sumber, yaitu hasil wawancara, catatan lapangan, dokumen-dokumen, dan lain-lain. Setelah itu mereduksi data, memaparkan data, dan simpulan melalui pelukisan dan verifikasi (Endraswara, 2006:176).

\section{PEMBAHASAN}

\section{Geografis dan Monografis}

Manado merupakan ibukota Provinsi Sulawesi Utara (Sulut), yang berbatasan dengan; Sebelah Utara Kecamatan Wori (Kabupaten Minahasa) dan Teluk Manado, Sebelah Timur dengan Kecamatan Dimembe, Sebelah Selatan dengan Kecamatan Pineleng, dan Sebelah Barat dengan Teluk Manado/Laut Sulawesi.

Secara administratif, Kota Manado mengalami pemekaran kecamatan pada 2014. Jika sebelumnya terdapat sembilan kecamatan, saat ini menjadi 11 kecamatan. Jumlah kelurahan di Manado tidak mengalami perubahan, yakni 87 kelurahan/desa dengan luas wilayah sebesar 157,26 km2. Kecamatan yang mengalami pemekaran adalah Tikala dan Bunaken. Wilayah Tikala ditambah satu lagi kecamatan, yaitu Paal 2. Demikian pula Bunaken menjadi dua kecamatan, yakni Bunaken dan Bunaken Kepulauan. Sementara, penduduk di Manado berjumlah 419.596 jiwa, dengan perincian lakilaki berjumlah 210.706 dan perempuan, 208.890 jiwa.Sementara itu, tempat peribadatan di Manado berdasarkan BPS tahun 2015 adalah 597 gereja, 199 masjid dan 36 mushalla, empat pura, dan 18 vihara/TITD (BPS Kota Manado, 2015)

\section{Mencermati Statistik Agama; Kontestasi Kelompok Mayoritas dan Minoritas}

$\begin{array}{ccr}\text { Sangat } & \text { sulit } & \text { mengorek } \\ \text { informasi } & \text { mengenai } & \text { jumlah } \\ \text { penduduk } & \text { berdasarkan agama di } \\ \text { Manado. } & \text { Badan Pusat } & \text { Statistik }\end{array}$ (BPS), yang selama ini selalu mencantumkan penduduk berdasarkan agama, kini sudah tidak mencantumkan lagi. Di dalam BPS "Manado dalam Angka 2015" di halaman 173, tabel jumlah penduduk berdasarkan agama tetap ada, tetapi kolomnya dibiarkan kosong, alias tidak ada data yang dimasukkan di situ. Pegawai BPS di Manado ketika dikonfirmasi meminta untuk menanyakan langsung ke kementerian agama kota atau kantor wilayah kementerian agama Sulut sebagai instansi yang berwenang. Selama ini, pihak BPS hanya menerima data-data dari kemenag, dan kemudian memasukkan datadata tersebut ke dalam kolom Manado dalam Angka. Ketika dikonfirmasi di kemenag kota dan provinsi, mereka juga ternyata belum 
menyediakan data-data terbaru, dan mengaku hingga kini masih proses penginputan data (Syuhudi, 2016).

Badan Pusat Statistik (BPS)

Manado sebagai medium tidak lagi mencantumkan data-data pemeluk agama setelah 2013. Ada kekhawatiran dari pemerintah setempat untuk mencantumkan jumlah penganut agama sejak 2008. Terlebih, sejak adanya tren kenaikan penduduk beragama Islam yang hampir seimbang dengan penduduk Kristen, sehingga demi menjaga status quo sebagai kota Kristen, pemerintah setempat tidak lagi mencantumkan jumlah penduduk berdasarkan agama. Hal ini juga berkaitan erat dengan persoalan penguasan lahan politik atau representasi identitas. Jadi, ada semacam kekhawatiran kota ini akan dipimpin oleh orang muslim, yang dikhawatirkan dapat memicu lahirnya konflik sosial (Sumampouw, 2015:117). Selain itu, tidak dicantumkannya data-data jumlah pemeluk agama di BPS, disebabkan oleh adanya sikap saling mengklaim di antara umat Islam dan Kristen di Manado. Persoalan ini kemudian menjadi politis, lantaran berebut posisi siapa yang menempati mayoritas dan minoritas. Orang Islam mengaku jumlah mereka kini berimbang atau hampir berimbang dengan umat Kristen di Manado. Sebaliknya, orang Kristen di Manado pun menampik, jumlah mereka tetap yang terbanyak.

Ini dapat dilihat dengan jabatan "kosong satu" di provinsi (gubernur) dan kota (walikota) yang hingga kini selalu dipegang oleh orang Kristen, atau istilah Sumampouw (2015:116), gubernur dan walikota selalu didominasi PKK (Pasangan KristenKristen) ketimbang PKI (Pasangan Kristen Islam).

\section{Relasi Sosial Pra dan Pasca Kehadiran PBM 2006}

Dampak negatif kehadiran PBM tahun 2006 di Manado (dan Sulut) adalah sudah banyak rumah ibadat yang dilarang dibangun. Yang paling merasakan adalah umat Islam. Beberapa masjid yang rencana dibangun di Manado, Bitung, Minahasa Tenggara, dan Minahasa Utara, terpaksa batal dibangun, karena tidak mendapat persetujuan warga sekitar. Padahal dulu, kalau ada orang Kristen punya tanah kosong, mereka menghibahkan kepada umat muslim untuk membangun masjid. Begitupula sebaliknya.

Di Manado, beberapa masjid yang berada di lingkungan perumahan mayoritas Kristen dilarang dibangun. Alasannya, warga muslim di perumahan tersebut dianggap oleh orang Kristen belum mencukupi untuk membangun sebuah masjid. Alhasil, dua kali Ramadhan warga muslim di perumahan itu melaksanakan Tarwih di rumah salah seorang warga.

Yang paling menyita perhatian adalah sengketa Masjid Al-Khairiyah di Kampung Texas, Manado. Tim Watimpres, Kyai Hasyim Musadi, bahkan sempat terbang ke Manado untuk mengetahui duduk persoalan masjid ini. Menurut Imam Masjid Al-Khairiyah, Hariyanto Ali, Hasyim tetap memberikan dukungan agar renovasi masjid tetap dilanjutkan hingga selesai setelah mengetahui duduk perkaranya. Kendati renovasi masjid telah dilakukan beberapa 
bulan lalu, pemerintah kota (pemkot) hingga kini belum memberikan restu.

Salah satu bentuk penolakan pemkot adalah tidak memberikan bantuan/sumbangan kepada masjid tersebut. Termasuk, adanya isu kalau pegawai negeri muslim di jajaran Pemerintah Kota Manado dilarang memberikan sumbangan. Menurut Hariyanto, bahan material bangunan masjid kebanyakan berasal dari hasil "celengan" Jumatan dan donator muslim. Pegawai negeri muslim yang memberikan bantuan meminta namanya dirahasiakan, lantaran dikhawatirkan berbenturan dengan pemerintah. "Misalkan ada sumbangan dari pegawai Bank yang memberikan bantuan 100 sak semen. Ada juga pegawai negeri dan pengusaha memberikan bantuan semen dan bahan material lainnya," kata Hariyanto.

Pada 2014, pemkot ingin membangun Graha Religi, semacam miniatur semua rumah ibadat di satu lahan. Selain masjid, akan didirikan pula gereja, pura, vihara, dan klenteng. Akan tetapi, rumah ibadat lainnya hanya simbolis, dan tidak digunakan untuk beribadah, kecuali Masjid Al-Khairiyah yang sejak tahun 1968 sudah berdiri dan digunakan shalat. Meski begitu, pengurus masjid dan sebagian warga muslim tetap menolak. Mereka resisten masjid digabung dengan rumah ibadat lain di satu lahan, meski hanya simbolis.

Hal inilah yang kemudian menimbulkan aksi demontrasi dari beberapa organisasi adat Minahasa berbasis agama Kristen. Namun sekarang (hingga Maret 2017), belum terdengar lagi gelombang aksi demonstrasi secara terang-terangan terhadap renovasi masjid itu. Lambat-laun, beberapa petak lahan kosong yang dulunya buat rumah ibadat simbolis telah dijual oleh pemiliknya, dan kini dibanguni rumah toko.

Umat Kristen sebagai mayoritas di Manado seringkali merasa paranoid terhadap hal-hal yang berbau pembangunan fisik rumah ibadat umat Islam. Setiap kali umat Islam merencanakan mendirikan sebuah bangunan di suatu tempat, umat Kristen selalu saja menaruh curiga. Hal inilah yang kerap kali menyebabkan beberapa bangunan yang bercirikan Islam menjadi terbengkalai. KUA Wenang, misalkan. KUA Wenang hingga kini belum memiliki kantor resmi, dan hanya menumpang di Kantor Kemenag Kota Manado. Sebenarnya, ada lahan kosong untuk diproyeksikan buat mendirikan KUA Wenang. Hanya saja, belum terbangun sampai saat ini, karena mendapat pertentangan dari orang Kristen yang tinggal di sekitar situ. Mereka beranggapan, bangunan yang akan didirikan adalah masjid atau pondok pesantren. Beberapa tukang yang awalnya bekerja terpaksa menghentikan pekerjaannya. Para tukang itu tidak tahan mendapat teror orang Kristen di situ.

Kemenag dianggap belum banyak membantu dan belum mampu menjadi mediator terkait problematik pendirian rumah ibadat, terutama pendirian masjid. Kasus Masjid AlKhairiyah yang belum tuntas, serta beberapa masjid di kompleks perumahan yang dilarang dibangun dengan alasan tidak mendapat persetujuan warga sekitar (non muslim), menjadi salah satu 
buktinya. Hal ini ditunjukkan pula oleh sebagian umat Islam di Manado, yang umumnya menolak mengadukan persoalan mereka (larangan membangun masjid) kepada kemenag. Sehingga, ada yang menuding, kemenag sulit menyelesaikan masalah pendirian masjid, lantaran mendapat tekanan dari tokoh-tokoh agama serta kelompok identitas berbasis agama Kristen. Umat Islam berharap, kemenag semestinya juga aktif "menjemput bola" untuk melihat berbagai persoalan yang dihadapi umat di tengah masyarakat. Bukan malah sebaliknya, mengetahui persoalan tersebut tetapi kemudian mendiamkannya. Di samping itu, adanya larangan mendirikan masjid menunjukkan, sosialisasi PBM nomor 9 dan 8 tahun 2006 tampaknya belum berjalan maksimal. Buktinya, sebagian orang di Manado belum mengetahui dan juga multitafsir dalam membaca isi regulasi PBM, terutama Bab IV pasal 13 dan pasal 14.

\section{Sulitnya Membangun Rumah Ibadat}

Sebagian besar orang di Manado berpendapat, regulasi PBM nomor 9 dan 8 tahun 2006 sebagai penyebab mereka sulit membangun rumah ibadat di daerah ini. Regulasi PBM juga dianggap sebagai salah satu penyebab timbulnya ketegangan antarumat beragama. Padahal, sebelum regulasi tersebut terbit, orang di Manado (dan Sulut) mudah membangun rumah ibadah di lokasi mana pun, sepanjang mereka memiliki lahan kosong. Tidak pernah ada umat dari agama lain yang menentang. Respon mereka selalu positif, dan terkadang di antara umat beragama itu saling membantu dalam pendirian rumah ibadat, baik membelikan bahan material bangunan, dan menyumbang tenaga. Namun, sejak regulasi tersebut terbit, relasi antarumat beragama terkait pendirian rumah ibadat mulai tampak kurang harmonis. Orang tidak bisa lagi sembarangan mencari atau memilih lokasi, karena semuanya harus mengacu kepada regulasi yang tertera di dalam PBM.

"Dulu, ketika membangun masjid, ketua pembangunan masjidnya adalah Pak Pendeta. Dan, pendeta ini sering mengerahkan jamaatnya untuk ikut membantu pembangunan masjid. Sebaliknya, ketika umat Kristen membangun gereja, kamid dari umat Islam juga ikut membantu. Misalkan dengan mengangkat batu, membantu mengecor, dan sebagainya. Nah, sejak berlakunya PBM, jangankan ikut membantu, baru mau akan membangun saja sudah timbul masalah. Harus ada jamaahnyalah, harus disetujui warga sekitarlah. Dulu, kami membangun rumah ibadat saling berdekatan, dan tidak ada masalah." (Wawancara, Kasi Urais Kanwil Kemenag Sulut, Kalo Tahirun, Maret 2017).

Dapat dikatakan, kehadiran PBM justru membuka ruang pemisah atau jarak sosial kehidupan antarumat beragama di Manado. Relasi antarumat beragama yang dulunya harmonis, kini menjadi disharmonis. Bagi sebagian orang 
Manado, PBM dianggap produk gagal dan tidak tepat diberlakukan di Manado (dan Sulut). PBM membuat mereka saling membenci dan saling mencurigai satu sama lain, yang ujung-ujungnya bisa menimbulkan keributan antarumat beragama. PBM juga, pada akhirnya, menjadikan mereka "berkotak-kotak". Sejak ada PBM, hampir tidak ada lagi tradisi saling tolong menolong antarumat beragama dalam mendirikan rumah ibadat.

Bagi orang Manado, regulasi PBM hanya cocok untuk daerah yang tingkat toleransi dan kerukunan antarumat beragamanya tergolong rendah. Regulasi PBM itu bersifat kontekstual, dan tidak bisa diberlakukan untuk semua wilayah di Indonesia. Boleh jadi, di daerah seperti Jawa sangat membutuhkan PBM untuk mengatur lalu lintas pendirian rumah ibadat. Terlebih, jika melihat dari banyaknya kasuskasus perusakan atau pelarangan umat agama lain yang melarang rumah ibadat agama lain berdiri di sekitar tempat tinggal mereka. Namun, di Manado, mereka sesungguhnya belum membutuhkan regulasi yang mengatur pendirian rumah ibadat. Jauh hari sebelum ada PBM, mereka tidak pernah saling melarang, karena selalu mengedepankan pendekatan kultural. Budaya "baku campur" masih kental mewarnai sebagian orang di Manado. Semua orang tanpa memandang identitas sosial bisa hidup rukun, karena adanya perkawinan lintas agama (kawin lintas agama merupakan pemandangan umum di Sulut, sehingga beberapa keluarga mempunyai keluarga atau kerabat yang berbeda agama dari mereka).

\section{PENUTUP}

Relasi sosial kelompok agama mayoritas dan minoritas di Kota Manado sesungguhnya, tergolong harmonis. Namun, kadangkala, keharmonisan antarpemeluk agama tersebut terkadang ternodai, terutama berkaitan pendirian rumah ibadat. Sejak PBM nomor 9 dan 8 tahun 2006 diberlakukan, pemeluk agama tertentu tidak lagi bisa sembarangan memilih lokasi untuk mendirikan rumah ibadat mereka. Padahal, sebelum regulasi PBM tahun 2006 terbit, masing-masing dari pemeluk agama sangat kompak, serta saling bantu membantu mendirikan rumah ibadat.

Melihat realitas tersebut,bila membandingkan kondisi sebelum dan setelah berlakunya PBM nomor 9 dan 8 tahun 2006, bisa dikatakan, regulasi tersebut belum tepat diberlakukan di Kota Manado saat ini.

\section{DAFTAR PUSTAKA}

BPS Kota Manado, 2015.

Endraswara, Suwardi. 2006. Metode, Teori, Teknik Penelitian Kebudayaan. Ideologi, Epistemologi, dan Aplikasi, Pustaka Widyatama, Yogyakarta.

Endraswara, Suwardi. 2006. Metode Penelitian Kebudayaan, Gadjah Mada University Press, Yogyakarta.

Kustini (ed). 2009. Efektivitas Sosialisasi Peraturan Bersama 
Menteri Agama dan Menteri Dalam Negeri Nomor 9 dan 8 Tahun 2006. Laporan Hasil Penelitian Puslitbang Kehidupan Keagamaan Badan Litbang dan Diklat Kementerian Agama RI.

Moleong, Lexi J., 2000. Metode Penelitian Kualitatif, RosdaKarya, Bandung.

Kapolri: Yang tak Boleh, Fungsi Rumah Jadi Mesjid dan Gereja, dalam http://www.tribunnews.com/na sional/2014/06/04/kapolriyang-tak-boleh-fungsi-rumahjadi-mesjid-dan-gereja, diakses pada 3 Juni 2014.

Peraturan Bersama Menteri Agama dan Menteri Dalam Negeri Nomor 9 dan 8 Tahun 2006 tentang Pedoman Pelaksanaan Tugas Kepala Daerah/Wakil Kepala Daerah dalam Pemeliharaan Kerukunan Umat Beragama, Pemberdayaan Forum Kerukunan Umat Beragama, dan Pendirian Rumah Ibadat, Sekretariat Badan Litbang dan Diklat Departemen Agama RI, cetakan pertama 8 Mei 2006, Jakarta.

Liliweri, Alo. 2005. Prasangka \& Konflik. Komunikasi Lintas Budaya Masyarakat Multikultur, LKiS, Yogyakarta.

Puslibtang Kehidupan Keagamaan. 2011. Kasus-Kasus Rumah Ibadat di Kawasan Timur Indonesia (Khusus Rumah
Ibadat Agama Islam). Laporan Hasil Penelitian.

Pusat Bahasa Depertemen Pendidikan Nasional. 2008. Kamus Bahasa Indonesia. Jakarta: Pusat Bahasa Depdiknas.

SETARA Institute. 2011. Negara Menyangkal, Kondisi Kebebasan Beragama/Berkeyakinan di Indonesia 2010, SETARA Institute, Jakarta.

Sumampouw, Nono S. A. 2015. Menjadi Manado, Torang Samua Basudara, Sabla Aer, dan Pembentukan Identitas Sosial, Gadjah Mada University Press, Yogyakarta.

Suparlan. 1995. Orang Sakai di Riau, Masyarakat Terasing dalam Masyarakat Indonesia, Yayasan Obor Indonesia, Jakarta.

Syuhudi, M. Irfan. 2014. Pendirian Rumah Ibadat Pasca PBM Nomor 9 dan 8 tahun 2006 di

-------. 2017. Pelayanan Kementerian Agama terhadap Penganut Agama Minoritas di Kota Manado, Laporan Penelitian, Belum diterbitkan, Balai Litbang Agama Makassar, Makassar.

Kota Kendari, Laporan Penelitian, Belum diterbitkan, Balai Litbang Agama Makassar, Makassar. 
Jurnal Pusaka, Vol. 5, No.1, 2017

The Wahid Institute 2011, Laporan Kebebasan Beragamal Berkeyakinan dan Toleransi 2010, The Wahid Institute, Jakarta. 